\title{
A juvenile Koskinonodon perfectus (Temnospondyli, Metoposauridae) from the Upper Triassic of Arizona and its implications for the taxonomy of North American metoposaurids
}

\author{
Bryan M. Gee ${ }^{1}$ and William G. Parker ${ }^{2}$ \\ ${ }^{1}$ Department of Biology, University of Toronto at Mississauga, Ontario L5L 5L1, Canada 〈bryan.gee@mail.utoronto.ca〉 \\ ${ }^{2}$ Division of Science and Resource Management, Petrified Forest National Park, Arizona 86028, USA 〈william_parker@nps.gov〉
}

\begin{abstract}
Metoposaurids are temnospondyl amphibians that are well known from Upper Triassic deposits in North America, Europe, India, and Africa. Two species of metoposaurids, Koskinonodon perfectus and Apachesaurus gregorii, are among the most common fossils found in the Petrified Forest National Park (PEFO) of the southwestern United States. The two are distinguished on the basis of several cranial traits and the morphology of their intercentra, and are more informally distinguished by their overall size and biostratigraphic range. While material of adult metoposaurids is extremely common in Upper Triassic deposits, described material of juveniles is very rare, which limits the study of ontogenetic trajectories that would assist in assessing whether diagnostic traits of the smaller A. gregorii are also ontogenetically influenced traits in juveniles of $K$. perfectus. Here we report on material from a juvenile specimen of $K$. perfectus from the Petrified Forest Member (Norian) of the Chinle Formation in the PEFO. This specimen is significant because it represents the highest known occurrence of the species within the PEFO, documents a rare occurrence of a juvenile specimen of a North American metoposaurid, and records a rare North American metoposaurid specimen that includes associated cranial and postcranial material. Additionally, the combination of cranial features diagnostic of $K$. perfectus and intercentra of proportions intermediate between $K$. perfectus and A. gregorii in this specimen raises questions about the utility of several characters for species discrimination in North American metoposaurids.
\end{abstract}

\section{Introduction}

Metoposaurids are Late Triassic temnospondyl amphibians with a global distribution and are some of the most commonly recovered fossils in freshwater depositional settings (Colbert and Imbrie, 1956). Three species of metoposaurids are currently recognized from North America: (1) Koskinonodon perfectus Case, 1922; (2) "Metoposaurus" bakeri Case, 1931; and (3) Apachesaurus gregorii Hunt, 1993. Both K. perfectus and A. gregorii are known from the Chinle Formation exposures of the Petrified Forest National Park (PEFO) (Long and Murry, 1995). Koskinonodon was previously distinguished from Metoposaurus Lydekker, 1890 solely by the presence of a lacrimal that contacts the orbit (Hunt, 1993); however, the utility of this character is uncertain because this feature was identified in the holotype of M. diagnosticus Meyer, 1842 from Germany (Sulej, 2002; but see Lucas et al., 2007) and subsequently in M. krasiejowensis (Sulej, 2007) and M. algarvensis (Brusatte et al., 2015). The diagnostic features of Apachesaurus that are most frequently preserved include the presence of shallow otic notches, an absence of tabular horns, an occiput that does not project posteriorly, and elongate intercentra (Hunt, 1993; Spielmann and Lucas, 2012). However, the ontogeny of North American metoposaurids is poorly understood because of a paucity of juvenile specimens, rendering it difficult to verify that these diagnostic features of Apachesaurus are not found in immature forms of already known metoposaurids, such as Koskinonodon. Additionally, complete skull material of A. gregorii is very rare, with the full set of diagnostic cranial characters known only from the holotype, and additional specimens referred to the taxon are too damaged to permit additional evaluation of the validity of these characters (Hunt, 1993; Spielmann and Lucas, 2012). The vast majority of postcranial material consists of the small, elongate intercentra, which are rarely associated or articulated with any diagnostic cranial material (Spielmann and Lucas, 2012). Finally, both size and stratigraphic position are used as informal characters to identify metoposaurid material, even though neither should be considered to be reliable for species discrimination (e.g., Irmis, 2007; Bell et al., 2010). Given these considerations, additional study of cranial material of small metoposaurids is especially important for helping to identify taxonomically informative features that are not confounded by ontogeny and that can distinguish juveniles of a large species from adults of a small species.

Here we describe cranial and postcranial material of a small metoposaurid (PEFO 35392) from the Petrified Forest Member (Upper Triassic, Norian) of the PEFO. Material from Norianage sediments that can be definitively assigned to K. perfectus is rare. Additionally, the presence of intercentra that are more 
elongate than is typical of large individuals of $K$. perfectus suggests that the specimen could belong to a mature individual of A. gregorii. However, the skull possesses features that are not diagnostic of the taxon, including: (1) a deep otic notch, (2) an occiput that projects posteriorly, and (3) a relatively wide cultriform process (Hunt, 1993; Spielmann and Lucas, 2012). Furthermore, a histological analysis of two intercentra belonging to this specimen as part of a broader survey of North American metoposaurid intercentra (Gee et al., 2017) reveals that these intercentra belong to a relatively immature individual. Given that cranial features are more phylogenetically informative than postcranial features, such as intercentra, which may be influenced significantly by habitat and general ecology, we tentatively assign the specimen to $K$. perfectus (Hunt, 1993; Long and Murry, 1995). Regardless of the taxonomic affinities, this material is not referable to A. gregorii.

\section{Geologic setting}

Locality information.-PEFO 35392 was collected in 2008 from locality PFV 215 (Zuni Well Mound) in the Petrified Forest National Park, Arizona, USA. Exact locality information is protected from disclosure by the Paleontological Resources Protection Act of 2009, but is available to qualified researchers from the Resource Management Division at the PEFO, see Figure 1.

Stratigraphic information.-PEFO 35392 was collected from the middle portion of the Petrified Forest Member (middle Norian) of the Chinle Formation (sensu Woody, 2006). The quarry is situated at the top of the Painted Desert Sandstone \#4 (Parker and Martz, 2011), 30 m below the Black Forest Bed of the Petrified Forest Member. The Black Forest Bed is a sandstone unit dominated by reworked tuffaceous material (Ash, 1992) and has provided a U/Pb date (sample BFB) of $209.926 \pm 0.072 \mathrm{Ma}$ from detrital zircons (Ramezani et al., 2011). This provides a minimum age for the quarry. The maximum age at the northern end of the PEFO is set by sample KWI, which is from the Brown sandstone (Billingsley, 1985) and which has a date of $213.870 \pm 0.078 \mathrm{Ma}$ (Ramezani et al., 2011). The Brown sandstone is $\sim 120 \mathrm{~m}$ below the quarry (Parker and Martz, 2011). Thus the estimated age of the quarry is closer to $211 \mathrm{Ma}$ (Nordt et al., 2015).

Other taxa found at this locality include phytosaurs (PEFO 36745), large-bodied metoposaurids (PEFO 31173), drepanosaurids (PEFO 36743), the archosauriform Vancleavea campi Long and Murry, 1995 (PEFO 34035; Parker and Barton, 2008), a rauisuchid paracrocodylomorph (PEFO 36740), the aetosaurian Typothorax coccinarum Cope, 1875 (PEFO 16668), the pseudosuchian Revueltosaurus callenderi Hunt, 1989 (PEFO 16671), and a theropod dinosaur (PEFO 36741). Numerous small, elongate metoposaurid intercentra from this locality have been previously assigned to Apachesaurus gregorii (e.g., PEFO 31209; Parker and Martz, 2011), but these identifications are less certain given the conclusions of the present study. Typothorax coccinarum and $R$. callenderi are index taxa of the Revueltian biozone (Parker and Martz, 2011).

\section{Materials and methods}

PEFO 35392 was discovered by Katie Loughney (then of the University of Rhode Island) on May 30, 2008 during geological and paleontological investigations of PFV 215. The skull and associated vertebrae were found adjacent to where a partial skeleton of the archosauriform Vancleavea campi had been collected in 2004 (Parker and Barton, 2008). The bones from this locality are extremely friable and often 'explode' once uncovered. The intercentra were collected individually; however, the skull was badly weathered and was collected as a separate jacket. Before jacketing, the specimen was consolidated with heavy amounts of very thin Vinac ${ }^{\mathrm{TM}}$ (polyvinyl acetate beads dissolved in acetone). The skull was jacketed using several layers of plaster bandages on August 1, 2008 by WGP and it was noted at the time that the specimen consisted of the rear of the skull and that it was badly preserved ventrally (unpublished field notes at the PEFO, W.G. Parker, 2008). Upon collection, the specimen was assigned the field number WGP 08/48-3. The skull was prepped by Kenneth Bader in October of 2010 at the PEFO. Matrix was removed with pin vise and brushes. Thick Paraloid B-72 (Rohm and Haas) was used as the adhesive, and thin Paraloid B-72 was used as a consolidant to treat areas where the inner bone surface was highly fragmented. The anterior portion of the skull was recovered as a mass of matrix and shattered fragments. This area is held together by consolidant, but no features can be determined in these areas (labeled "mbf" in Fig. 2.2, 2.4).

For the histological analysis, the intercentra were first cleaned using a toothbrush and water to remove excess matrix before being consolidated with thin Paraloid B-72. All specimens were molded and casted according to the PEFO museum standards (National Park Service, 2007), with Carbowax (molecular weight 4000; Dow) added to stabilize cracks and other fragile areas. After creating two-part molds using Platsil 73-25 silicone rubber, the Carbowax was removed using a brush and warm water. All specimens were impregnated in a polyester resin mixture of Castolite ${ }^{\mathrm{TM}} \mathrm{AC}$ and hardener (Eager Polymers) at a ratio of one ounce of Castolite ${ }^{\mathrm{TM}}$ to 12 drops of hardener. The specimens were placed in a vacuum chamber to evacuate gas from the resin and then allowed to cure for a minimum of 24 hours. Both sagittal cuts (down the midline in the anteroposterior axis) and transverse cuts (at the mid-length along the mediolateral axis) were made based on the amount of ontogenetic information that could be derived from the different planes in the analysis of Konietzko-Meier et al. (2013). All specimens were cut using an automated IsoMet 1000 Precision Saw (Buehler). The cut surface of the desired block and its respective plexiglass slide were prepared by polishing each with a 600 mesh silicon carbide on a glass plate. Both surfaces were rinsed with ethanol and then attached using Scotch-Weld Instant Adhesive (CA40; 3M). The sections were allowed to dry for a minimum of 1 hour. All sections were cut to a height of $0.7 \mathrm{~mm}$ using the IsoMet 1000 Precision Saw. All specimens were then polished with a Hillquist 1010 grinding cup, followed by manual polishing on glass plates using a succession of 600 mesh grit, 1000 mesh grit, and 1 micron grit. The thin sections were gradually ground down with repeated examination under a compound microscope to evaluate their optical clarity. 

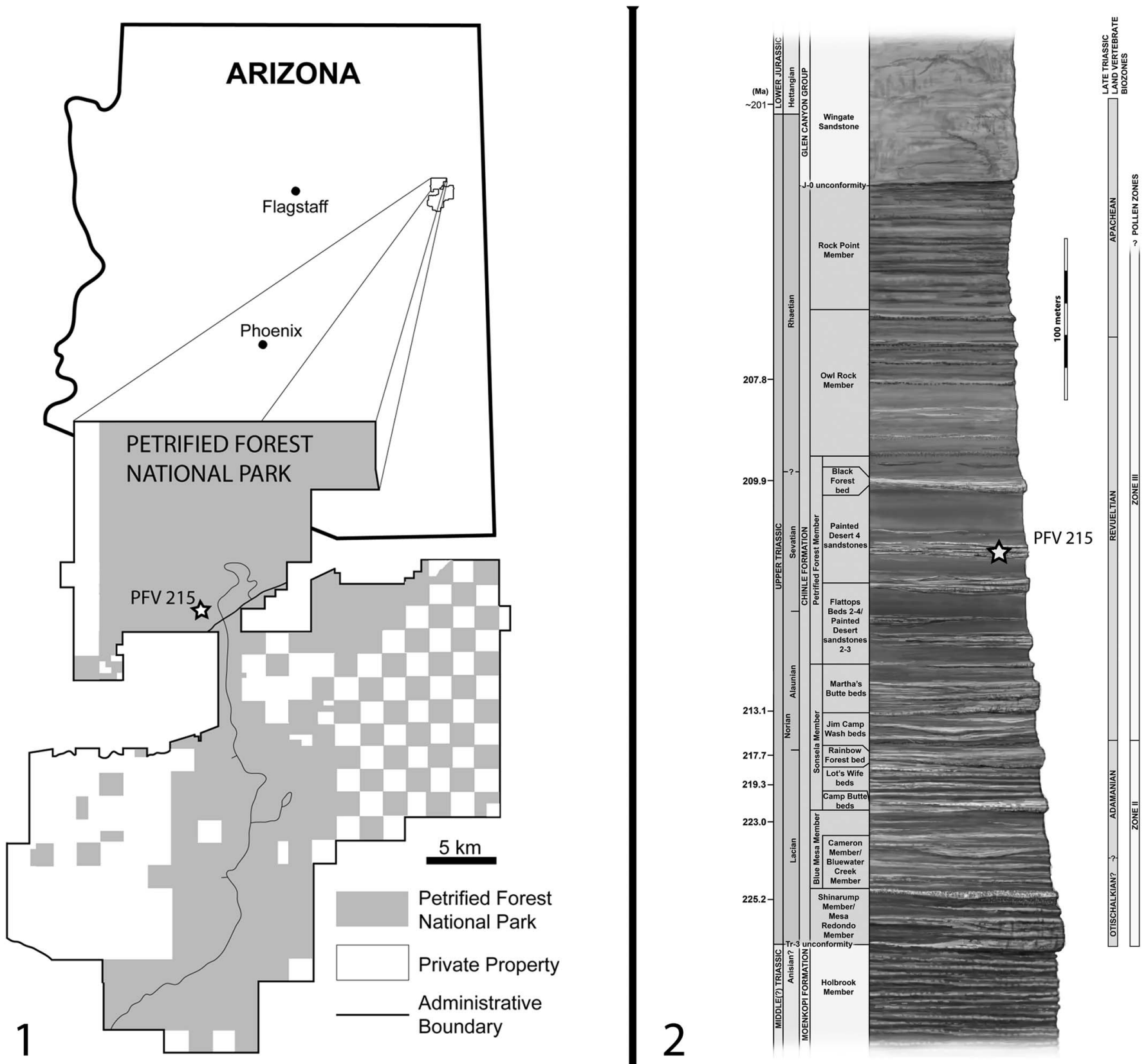

Figure 1. Geographic and stratigraphic information associated with the locality from which PEFO 35392 was collected: (1) locality map showing the locality of PFV 215 within the Petrified Forest National Park; modified from Parker and Irmis (2005); (2) composite stratigraphic section of the Chinle Formation in northeastern Arizona showing the stratigraphic position of PFV 215; stratigraphy follows Martz and Parker (2010) radioisotopic dates are from Ramezani et al. (2011).

Thin sections were imaged on a Nikon AZ100 Multizoom microscope fitted with AZ-Plan Apo 0.5x and AZ-Fluor 5x objective lenses, an AZ-RP rotatable polarizer plate, and a DSFi2 digital camera mount. NIS-Elements imaging software was used for this study.

Repositories and institutional abbreviations.-The described specimen is deposited at the Petrified Forest National Park (PEFO), USA. Previously described specimens that are referenced from other publications but not further evaluated here are deposited at the following repositories: Museum of Northern Arizona (MNA), Flagstaff, USA; Texas Memorial Museum,
Austin, USA (TMM); University of California Museum of Paleontology, Berkeley, USA (UCMP); University of Michigan Museum of Paleontology, Ann Arbor, USA (UMMP).

\section{Systematic Paleontology}

Order Temnospondyli Zittel, 1888 sensu Schoch, 2013 Suborder Stereospondyli Zittel, 1888 sensu Yates and Warren, 2000

Family Metoposauridae Watson, 1919

Genus Koskinonodon Branson and Mehl, 1929 
Koskinonodon perfectus (Case, 1922)

Figures 2-5

1922 Buettneria perfecta Case, pls. 1, 2A, 2B, figs. 1-3.

1956 Eupelor fraasi jonesi Colbert and Imbrie, p. 449, pls. 25.3, 25.4, 26.1, 26.2, figs. 7, 8 .

1965 Metoposaurus fraasi jonesi Chowdhury, p. 42.

1993 Buettneria perfecta Hunt, p. 78, figs. 7-9.

2007 Koskinonodon perfectum Mueller, 2007, p. 225.

Holotype.-Complete skull (UMMP 7475) from the Dockum Group, Crosby County, Texas, USA (Case, 1922, pls. 1, 2A, 2B, figs. 1-3).

Referred material.-Partial skull with associated ribs and intercentra (PEFO 35392) from the Chinle Formation, Petrified Forest National Park, Arizona, USA (Figs. 2-5).

Remarks.-Previously, the inclusion of the lacrimal into the orbital margin was the sole diagnostic character of Koskinonodon, which separated it from Metoposaurus, but the subsequent observation of a comparable condition to the former in the latter by more recent workers (Sulej, 2002, 2007; Brusatte et al., 2015; but see Lucas et al., 2007) has rendered it invalid. Therefore, the diagnosis of Koskinonodon is in need of revision, particularly with regard to its differentiation from other large-bodied metoposaurids. However, we do not attempt to amend the diagnosis in this paper in the absence of a broader revision of the Metoposauridae, which similarly requires extensive revision to evaluate existing autapomophies of the clade and to assess the potential for morphological differences to be attributable to intraspecific variation, ontogeny, or factors other than speciation. Additionally, although this specimen provides additional information on $K$. perfectus, the paucity of juveniles of other taxa inhibits an appropriate comparison of autapomorphies at this ontogenetic stage. Our taxonomic assignment of this material is based on the marked differences from the diagnosis of the small metoposaurid, Apachesaurus gregorii, and the current biogeographic distribution of metoposaurids in which $K$. perfectus is the only large-bodied metoposaurid west of Texas.

Description.-PEFO 35392 consists of a partial skull associated with several ribs and intercentra. The skull is modestly well preserved, with landmark features such as the pineal foramen, the left orbit, the left stapes, the left otic notch, and both occipital condyles visible in dorsal view, and features such as the parasphenoid and pterygoid visible in ventral view. The skull measures $\sim 15.4 \mathrm{~cm}$ from the posteromedial margin of the postparietals to the posterior margin of the orbit.

The dorsal surface of the skull (Fig. 2.1, 2.2) preserves a good amount of detail and landmark features, although it has been fractured in several locations, and the original sutures are not visible. Where the ornamentation is preserved, much of the skull is characterized by the typical honeycomb pattern found in temnospondyls, mostly consisting of semi-circular pitting of variable size with a small area of elongate grooves in the posterolateral lobe of the temporal region. The pits contain small, distinct foramina that provide a method to distinguish fragmentary temnospondyl material from ornamented osteoderms of amniotes such as aetosaurs, which lack these foramina (Witzmann et al., 2010). The posterior region of the skull is the best preserved. A large anteromedial portion of the skull, probably the snout, is present but obscured by encrusting matrix and bone splinters, which could not be removed without damaging the skull because this area is very thin. The left orbit is mostly preserved with the entire lateral and posterior margins intact (Fig. 2.1, 2.2). Portions of the anterior and anteromedial margins of the orbit are missing, and the posteromedial portion is dislocated into the orbit.

Several postcranial elements are pressed into the dorsal surface of the skull, including two nearly complete ribs and one partial rib posterior to the left orbit and a caudal intercentrum anterior to the pineal foramen; these are discussed further below. The pineal foramen is well defined, circular, and connected to a slightly raised ridge that extends both anteriorly and posteriorly along the midline (Fig. 2.1, 2.2). The best-preserved and mostdiagnostic portion of the skull is the posterior region, containing the otic region and the occiput. The otic notch (Fig. 2) is the most common feature used to identify specimens of North American metoposaurids, and in this specimen, it is relatively deep in comparison to described specimens of A. gregorii (Spielmann and Lucas, 2012). The surface is smooth and uninterrupted except for a small fracture that caused slight dislocation of the squamosal directly upward, suggesting that the incision is not the product of taphonomic damage. Further supporting the conclusion of a well-preserved otic region is the presence of an articulated stapes, the cylindrical distal end of which can be seen projecting posterolaterally in dorsal and occipital views (Figs. 2.1, 2.2, 3). The exposed region of the stapes is identical in form to that seen in other metoposaurids (Case, 1931; Dutuit, 1976; Sulej, 2007; Spielmann and Lucas, 2012; Brusatte et al., 2015). Medially, the otic notch forms a continuous surface with the tabular and the postparietal. Although no posterolaterally projecting tabular horn is present, this margin of the tabular appears to be weathered; thus we cannot conclusively determine whether the tabular horn was absent in this individual. The occiput can be seen projecting posteriorly beyond the posterior extent of the dorsal skull table. The right otic notch, in addition to most of the right side of the cranium, is not preserved in this specimen.

The palatal surface of the skull (Fig. 2.3, 2.4) is similar to the dorsal surface in that the posterior portion is the best preserved and that the anterior portions are heavily damaged. The basal plate of the parasphenoid is fully preserved, although its sutures to the exoccipitals and the pterygoids are not identifiable. The basal plate is roughly diamond-shaped, with

Figure 2. Skull of juvenile Koskinonodon perfectus (Case, 1922) (PEFO 35392) from the Chinle Formation of the Petrified Forest National Park, AZ, USA: (1) photograph of dorsal view, (2) interpretive illustration of dorsal view, (3) photograph of ventral view, (4) interpretive illustration of ventral view. Abbreviations: $\mathrm{cp}=$ cultriform process; ect $=$ ectopterygoid; $i c=$ intercentrum; $\mathrm{fr}=$ frontal; ipw $=$ interpterygoid window; ju $=$ jugal; lac $=$ lacrimal; $\mathrm{mbf}=$ mass of bone fragments; oc = occipital condyle; on = otic notch; orb =orbit; par = parietal; pin = pineal foramen; po = postorbital; pof = postfrontal; ppar = postparietal; $\mathrm{psp}=$ parasphenoid; $\mathrm{pt}=$ pterygoid; $\mathrm{qj}=$ quadratojugular; $\mathrm{r}=\mathrm{rib} ; \mathrm{sq}=$ squamosal; $\mathrm{sta}=$ stapes; $\mathrm{stf}=$ subtemporal fenestra; sup $=$ supratemporal; tab = tabular Scale bars $=5 \mathrm{~cm}$. 

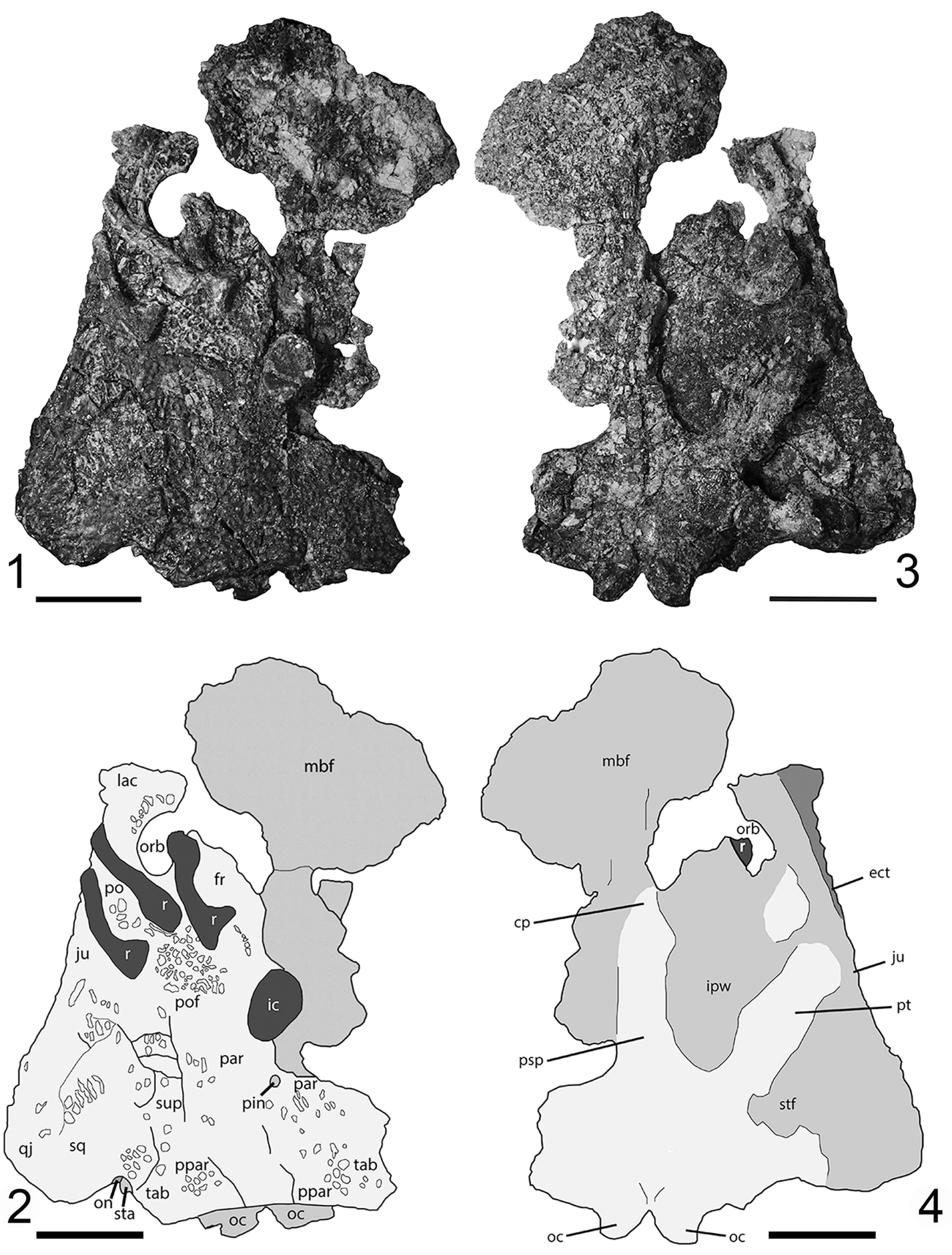


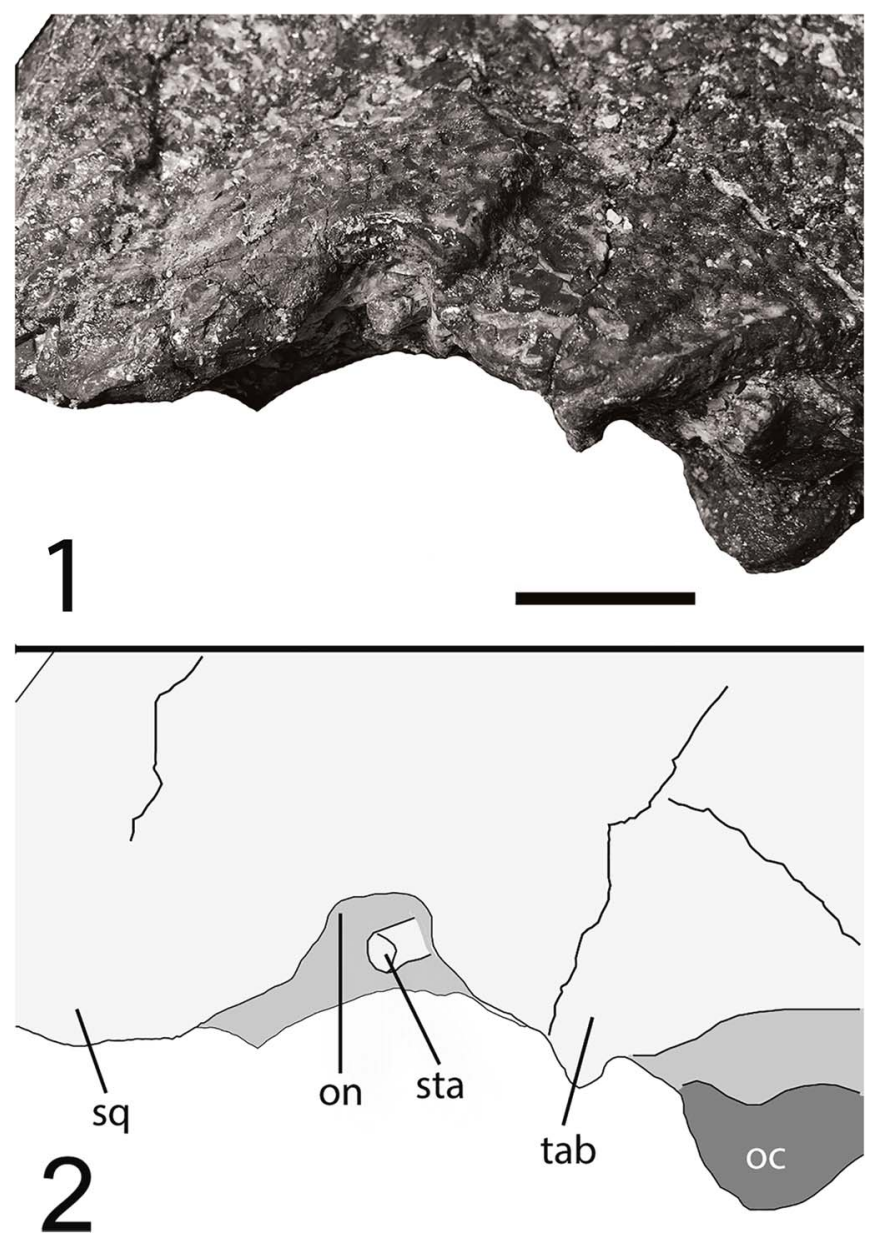

Figure 3. Skull of juvenile Koskinonodon perfectus (PEFO 35392) from the Chinle Formation of the Petrified Forest National Park, AZ, USA in left occipital view: (1) photograph, (2) interpretive illustration. Abbreviations: oc = occipital condyle; on = otic notch; sq = squamosal; sta = stapes; $\mathrm{tab}=$ tabular. Scale $\mathrm{bar}=2 \mathrm{~cm}$.

the long axis oriented in the anteroposterior direction. The anteriorly projecting cultriform process is partially preserved and contributes to the medial and posterior margins of the large, oval interpterygoid vacuities. The lateral margin and the remainder of the posterior margin of the interpterygoid vacuities are formed by the pterygoid, which projects anterolaterally from its union with the parasphenoid. The left pterygoid is partially complete, with posterior portions of the anterolateral and posterolateral processes intact. Of the right pterygoid, only the main base and a portion of the posterolateral process are preserved. The occipital condyles are well exposed in ventral view and are fully attached to the pterygoid and the parasphenoid. The anteriormost extent of the skull is mostly obscured by a combination of encrusting clay matrix and bone splinters that cannot be removed without damaging the specimen because these areas are relatively thin and brittle.

Several cranial features were identified as informative for distinguishing this specimen from the nearly complete holotype of $A$. gregorii (UCMP 63845). In general, the profile of the skull of PEFO 35392 in dorsal view is more similar to that of large metoposaurids in that the postorbital region is more broadly expanded mediolaterally to produce a temporal lobe that is more pronounced than in the holotype of A. gregorii. This does not appear to be the result of taphonomic damage to the posterolateral corner in the latter considering that the subtemporal fenestra is completely enclosed on the right side (Spielmann and Lucas, 2012, fig. 10). PEFO 35392 is also notably larger; from the posteromedial margin of the postparietal to the posterior margin of the orbit, PEFO 35392 measures $15.4 \mathrm{~cm}$ in comparison to UCMP 63845, which measures $\sim 10.3 \mathrm{~cm}$ over the same distance. Both are larger than a juvenile $K$. perfectus (TMM 31099-12B) that was photographed but not described by Hunt (1993, fig. 8A, 8B), which measures $\sim 8.7 \mathrm{~cm}$ over the same interval. All three skulls are significantly smaller than the largest known skulls of $K$. perfectus, which are documented at complete skull lengths in excess of $60 \mathrm{~cm}$ (Long and Murry, 1995). The otic notch is deeper in PEFO 35392 than in specimens of A. gregorii, as in large metoposaurids with the exception of the intermediate depth of notches in Arganasaurus lyazidi (Dutuit, 1976). As previously noted, this incision does not appear to have been further exaggerated during preservation (Fig. 3). On the palatal surface, the cultriform process is wider in PEFO 35392 than in the holotype of A. gregorii; the ratio of the maximum skull width to the minimum process width, a metric defined by Hunt (1993), is 15.6 in PEFO 35392 and is 19.8 in UCMP 63845 (Fig. 2.3, 2.4). The cultriform process of TMM $31099-12 \mathrm{~B}$ is relatively wider ( 9.3) than in both of these specimens. Additionally, the transverse process of the pterygoid in A. gregorii is significantly more constricted at its mid-length than appears to be the condition in the partial left transverse process in PEFO 35392. Finally, the occiputs project posteriorly in PEFO 35392 (Fig. 2.1, 2.2) as in TMM 31099-12B, whereas they are preserved but covered by the postparietals and tabulars dorsally in UCMP 63845. The lack of preserved sutures in both PEFO 35392 and in additional specimens of A. gregorii beyond the holotype renders a comparison of sutural patterns impossible at this time.

The postcranial material included in PEFO 35392 consists of nine intercentra and four partial ribs (Figs. 2.1, 2.2, 4). Three of the ribs are pressed into the dorsal surface of the skull posterior to the left orbit and cannot be removed without damaging the specimen. Two are relatively complete, while the third only preserves the proximal end. The posteriormost rib appears to be complete, with a broad proximal end that becomes more slender at the curved shaft and flattened at the distal end. The second complete rib in this area is more elongate, with a narrower proximal end that is only slightly wider than the shaft. It is slightly sinuous, curving gently toward the orbital margin in the proximal half and curving slightly away from the margin in the distal half. The proximal end of the partial rib in this region is more oval in cross-section than the other two ribs, giving it greater height. A possible fourth rib is located in the anteromedial region of the skull and is embedded in finegrained matrix and bone splinters. It also has a more pronounced height than the two complete ribs and appears to narrow at the shaft. The preserved portion is not curved, hence our tentative identification of the element. The lack of curvature and the anteromedial position would be consistent with a basibranchial, a bone known in only one specimen of $M$. diagnosticus (Witzmann, 2013), but the element is too incomplete to confidently resolve its identity. Assignment of the position of 

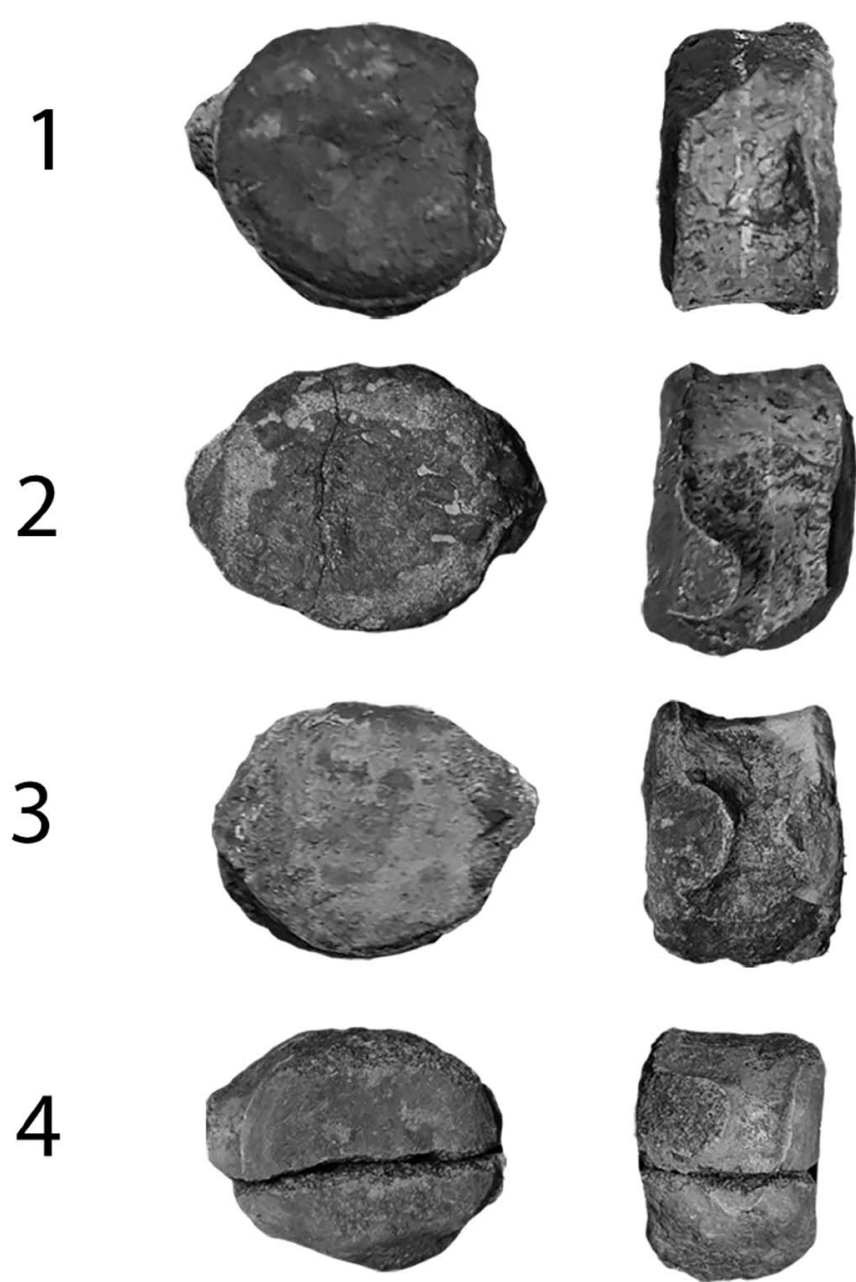

5
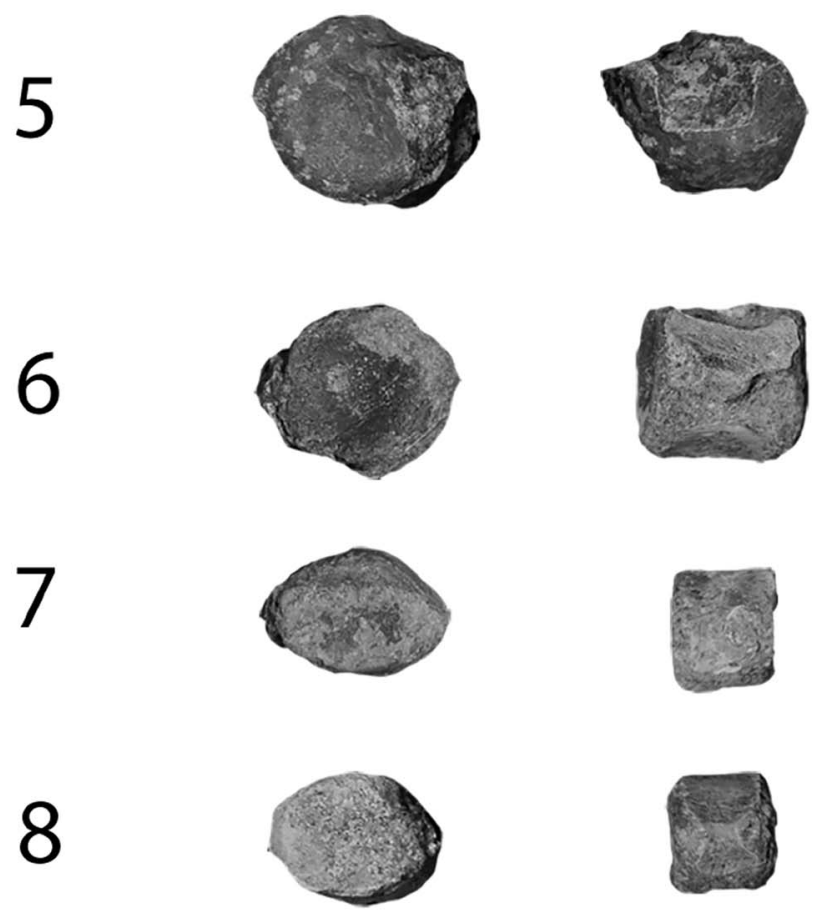

disarticulated ribs is difficult in metoposaurids given the lack of articulated reference specimens with the ribs in place and the subsequent difficulty in differentiating morphological changes associated with position from those associated with ontogeny (Sulej, 2007). Based on comparisons to the described ribs of M. diagnosticus krasiejowensis (Sulej, 2007), the posteriormost rib can be tentatively assigned as an anterocaudal rib based on its strong curvature and relatively short length. The second rib, located posterior to the orbit, does not conclusively match the description of any described rib, which suggests that it may have been taphonomically deformed to produce the sinuosity. The anteriormost rib, located posteromedial to the orbit, is similar in morphology to the rib assigned as an anterocaudal based on its curvature and length. The potential fourth rib is too fragmented to assign a position. Because of the disarticulated nature of North American metoposaurid material, ribs that can confidently be assigned to A. gregorii have never been described, preventing any comparison with the taxon.

A total of nine intercentra were found associated with the skull, including one that is pressed into the dorsal surface anterior to the pineal foramen (Figs. 2.1, 2.2, 4; Table 1). The intercentra are of various sizes and proportions, but eight of the nine are modestly elongate (Fig. 4.1-4.5 4.7-4.8; Table 1). The remaining intercentrum is of elongate proportions that are characteristic of A. gregorii (Fig. 4.6, Table 1). Based on comparisons of the diameter-to-length ratio in these intercentra to those of other North American metoposaurids of various sizes and provenance, several intercentra of this specimen are within the upper limits of the range of values for A. gregorii, but a few of the larger intercentra fall within the lower limits of the range of larger metoposaurids (unpublished data, B.M. Gee, 2017). Accordingly, we consider them to be of a more intermediate degree of elongation. As with the ribs, the precise positions of the vertebrae are somewhat difficult to extrapolate, especially since all comparisons of postcrania are generally made with $M$. diagnosticus krasiejowensis, which might not be representative of the North American metoposaurids. Intercentra can be generally divided into precaudal and caudal based on the presence of prezygapophyses and parapophyses in the former, deep ventral furrows extending from the anterior to the posterior surface in the latter, and the nature of the anterior articular surface (flat versus convex and overall depth of depression when convex) (Sulej, 2007; Spielmann and Lucas, 2012). All assignments are tentative given the uncertainty regarding potential morphological variation in the axial column among metoposaurids. The intercentrum impressed onto the skull (Fig. 2.1,2.2) is caudal in position based on the absence of any lateral projections and the presence of the broken base of the chevron. It was probably relatively close to the sacrum given the reduced elongation in comparison to the posteriormost caudal elements. Of the separately collected intercentra, the largest four (Fig. 4.1-4.4) are similar to the caudal intercentrum in both size and proportions, allowing for a confident association with this element and the cranium. Based on

Figure 4. Intercentra of juvenile Koskinonodon perfectus (PEFO 35392) from the Chinle Formation of the Petrified Forest National Park, AZ, USA; intercentra are ordered by overall size from 1 to 8 , with the anterior profile in the left column and the lateral profile in the right column; number designations and order correspond to those in Table 1 . Scale bar $=2 \mathrm{~cm}$. 

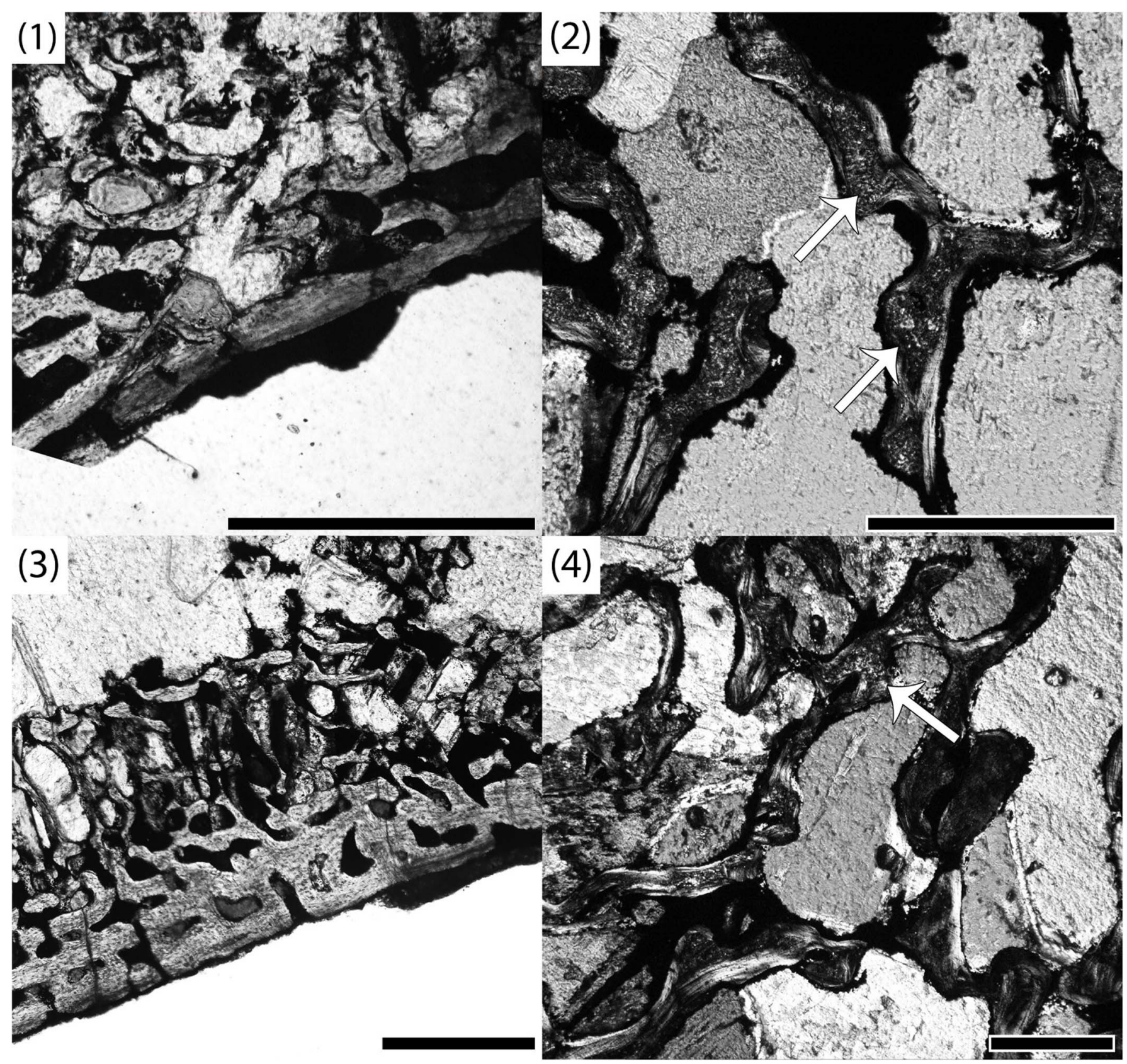

Figure 5. Microphotographs of the external cortex and calcified cartilage of two intercentra of PEFO 35392 in sagittal section: (1) external cortex of PEFO 35392c; (2) calcified cartilage (white arrows) in the same specimen; (3) PEFO 35392a; (4) calcified cartilage in the same specimen. Scale bars =1 cm (1, 3), $500 \mu \mathrm{m}(2,4)$

the posterior position of the parapophyses and the relatively flat anterior surface, all four are assigned to the range from mid-dorsal to perisacral. Two of these intercentra were selected for the histological analysis that is presented in part below. The other four intercentra (Fig. 4.5-4.8) can also be identified as pre-caudal based on the presence of the parapophyses and the smooth anterior surface. It is unclear whether these are associated with the cranium and the larger intercentra given the stark difference in size. Only one of the nine intercentra described here has a deep convexity on the anterior surface similar to previously described intercentra of A. gregorii (Hunt, 1993; Spielmann and Lucas, 2012). Although all nine are opisthocoelous, the notochordal pit is relatively shallow in the remaining eight, more so on the anterior surface, in contrast to typical intercentra of A. gregorii. The pit does not appear to connect the anterior and posterior surfaces; this morphology may be influenced by both ontogeny and axial position. This possibility and the axial position assignments designated here are only tentative at present and require more fully articulated vertebral columns of North American metoposaurids to verify.

Because associated or articulated vertebral columns of A. gregorii are rare (Spielmann and Lucas, 2012), a separate histological survey of metoposaurid intercentra from the PEFO was conducted with the intention to utilize the findings of Konietzko-Meier et al. (2013) to determine the ontogenetic maturity of various intercentra (Gee et al., 2017). Two of the 
Table 1. Measurement data for the intercentra associated with a juvenile specimen of $K$. perfectus (Case, 1922) (PEFO 35392). Numerical assignments for each element were created solely for the basis of this paper and are ordered from largest to smallest to correspond with Figure 4 with the exception of element 9 , the intercentrum on the dorsal surface of the skull that is not included in Figure 4. Diameter (D) was measured in the mediolateral axis, height $(\mathrm{H})$ was measured in the dorsoventral axis, and length (L) was measured in the anteroposterior axis in the same manner as measurements made by KonietzkoMeier et al. (2013). The length of element 9 could not be measured due to its position.

\begin{tabular}{llcccc}
\hline Specimen No. & Estimated position & $\mathrm{L}(\mathrm{mm})$ & $\mathrm{D}(\mathrm{mm})$ & $\mathrm{H}(\mathrm{mm})$ & $\mathrm{D}: \mathrm{L}$ \\
\hline 1 & mid-dorsal & 15.43 & 28.27 & 25.74 & 1.83 \\
2 & anterior dorsal & 14.55 & 27.30 & 25.15 & 1.87 \\
3 & anterior dorsal & 15.37 & 25.89 & 24.72 & 1.68 \\
4 & mid-dorsal & 14.42 & 24.47 & 23.83 & 1.69 \\
5 & precaudal & 11.17 & 16.91 & 16.44 & 1.51 \\
6 & precaudal & 14.03 & 16.56 & 15.52 & 1.17 \\
7 & precaudal & 9.48 & 14.68 & 12.30 & 1.54 \\
8 & presacral & 8.57 & 14.51 & 12.33 & 1.69 \\
9 & anterior caudal & - & 25.13 & 23.71 & - \\
\hline
\end{tabular}

intercentra of that study belong to PEFO 35392 and sections of this material are briefly described here. In sagittal profile, they are characterized by a relatively wide, ventral periosteal cortex, which is triangular with an apex that terminates at or below the mid-height of the intercentra. This region is made of a parallellayered matrix that has been partially damaged by secondary precipitation of carbonate minerals. In transverse profile, the periosteal cortex extends up the lateral margins from the ventral margin. The remainder of the internal structure consists of more randomly oriented endochondral trabeculae that are thickest at the articular faces and thinnest in the dorsal portion of the element. The intertrabecular spacing increases in the dorsal region. Calcified cartilage is abundant within the intercentra, including in the interior endochondral region; in M. krasiejowensis, calcified cartilage decreases in relative abundance throughout ontogeny, particularly in the interior of the intercentra (Konietzko-Meier et al., 2013). The presence of calcified cartilage in the interior of both intercentra is thus indicative of their relative immaturity (Fig. 5.2, 5.4). A weathered external cortex is preserved in both of the specimens, but it appears to still be relatively well vascularized and shows no evidence of a compact lamellar annulus or LAGs that would indicate relative maturity (Fig. 5.1, 5.3). Using the histological ontogenetic stage (HOS) designations of Konietzko-Meier et al. (2013), we designate these intercentra as HOS 3 based on the presence of a wide periosteal region (which originates in HOS 2) and an external cortex that is still relatively vascularized and lacking in LAGs (which originate in HOS 4).

\section{Discussion}

We refer PEFO 35392 to Koskinonodon perfectus based upon: (1) the presence of a relatively deep otic notch, (2) a projecting occiput, and (3) a relatively wide cultriform process, features that readily distinguish it from Apachesaurus gregorii, and the lack of documentation of "M." bakeri west of Texas (Hunt, 1993; Long and Murry, 1995). Although these anatomical features could be affected during preservation, as may also be the case in the holotype of A. gregorii, the histological examination of two of the associated intercentra provides a strong second line of evidence that the individual was relatively immature at the time of death. This ontogenetic assignment is based on several anatomical and histological features, such as the absence of a compact annulus at the ventral margin and an abundance of calcified cartilage, both of which have been identified as ontogenetically variable in $M$. krasiejowensis by Konietzko-Meier et al. (2013) (Fig. 5). It is noteworthy that this individual is still relatively immature in spite of being nearly $50 \%$ longer than the holotype of A. gregorii, which was interpreted as a mature individual (Hunt, 1993). While PEFO 35392 does not have a clear tabular horn, as is the condition of A. gregorii, it is common for the posterior margins of the skull to be weathered in taxa that normally possess a tabular horn (Fig. 2; personal observation, B.M. Gee, 2017). Therefore, the lack of a clear tabular horn in this specimen should not be automatically interpreted to mean that the structure was not present when the animal was alive, because the feature is narrow and flattened, making it susceptible to degradation and eventual loss. Both otic notch depth and variation in tabular horn shape and size have been recognized as ontogenetically variable features in other metoposaurids (Sulej, 2007), so it is also possible that the tabular horn was greatly reduced at this stage in development. Although these intercentra are not as elongate as the smaller intercentra that are characteristic of $A$. gregorii, they are more elongate than typical intercentra of $K$. perfectus, and past workers have ascribed intercentra of similar proportions to those of this specimen to A. gregorii (Fig. 4; Long and Murry, 1995; Spielmann and Lucas, 2012). The ontogenetic designation that results from the histological analysis is in agreement with the intermediate degree of elongation because this specimen represents an intermediate between the early post-metamorphic form and the significantly larger adult form. Accordingly, the intermediate proportions of the intercentra in this specimen suggest a somewhat rapid transition toward proportionately shorter intercentra that have traditionally characterized mature individuals. The acquisition of a morphology more similar to that of large, presumably mature forms early in ontogeny is not surprising; this has been demonstrated in the plagiosaurids, another family of Mesozoic temnospondyls with similar dorsoventral flattening of the skull and a presumed bottom-dwelling ecology (Schoch, 2009; Danto et al., 2016). Their accelerated developmental trajectory in comparison to other stereospondyls has been suggested to be the result of the selective pressure of predation risk that would have resulted from the relative immobility of these large stereospondyls (Schoch, 2009). It is not implausible to hypothesize a similar trajectory for metoposaurids, considering the broad morphological and inferred ecological similarities in morphology between the two families. If large metoposaurids acquired the adult morphology relatively early in ontogeny, this would confound efforts to identify the relative maturity of specimens based solely on their external features, as was the case in the original designation of $A$. gregorii as an adult by Hunt (1993). This possibility highlights the importance of multiple lines of analysis for determining the ontogenetic maturity of a specimen, such as in this study where we utilized both external morphology and histology.

Unfortunately, informative postcrania such as the intercentra are rarely directly associated with diagnostic cranial material 
in North American metoposaurids, especially A. gregorii (Spielmann and Lucas, 2012). The identification of isolated intercentra should be discouraged given the paucity of articulated or associated skeletons of $A$. gregorii that possess both elongate intercentra and diagnostic cranial material and of juvenile specimens of large metoposaurids (Long and Murry, 1995; Spielmann and Lucas, 2012). Additionally, past workers have emphasized cranial features over post-cranial features in species determination, which we continue to follow here given the greater phylogenetic utility of cranial characters (Hunt, 1993; Long and Murry, 1995). Presently, the only species of the genus is K. perfectus; although "Metoposaurus" bakeri has sometimes been placed in the genus, it lacks a lacrimal that enters the orbit, which is the diagnostic feature of Koskinonodon (Hunt, 1993). Given that recent authors no longer consider this character valid for distinguishing between the two genera, the taxonomic placement of the species remains unresolved (Sulej, 2002; Brusatte et al., 2015; but see Lucas et al., 2007). Additional discussion of the character is beyond the scope of this paper, but regardless of its taxonomic placement, material of "M." bakeri in the southwest of North America is mostly restricted to the Dockum Group of Texas, with a single documented occurrence in Nova Scotia (Case, 1932; Hunt, 1993; Long and Murry, 1995). Koskinonodon perfectus is the most widespread and most commonly recovered metoposaurid, and skulls of adult specimens are known to exceed $60 \mathrm{~cm}$ (Colbert and Imbrie, 1956). Accordingly, PEFO 35392, with a length of $15.4 \mathrm{~cm}$ from the posteromedial margin of the skull to the posterior margin of the orbit, can be designated as a juvenile of the species (Long and Murry, 1995; Zanno et al., 2002). This is further supported by the histological analysis, which shows that the associated intercentra are relatively immature in spite of the larger size of the skull in comparison to the allegedly mature holotype specimen of A. gregorii. Koskinonodon perfectus is a commonly recovered fossil from the Adamanian land vertebrate faunachron (LVF) of the PEFO, but documentation of diagnostic material is rare in the Revueltian LVF (Hunt, 1993; Long and Murry, 1995; Heckert and Lucas, 2002; Parker and Martz, 2011). At present, PEFO 35392 represents the youngest confirmed occurrence of cranial material of $K$. perfectus within the park.

Although material belonging to adult specimens of the large North American metoposaurid taxa (K. perfectus and " $M$." bakeri) is extremely common in both the Chinle Formation and the Dockum Group, reports of material that can be conclusively identified as belonging to juvenile individuals of the two species are rare (Sulej, 2007). Material ascribed to juveniles has occasionally been documented (e.g., Hunt, 1993), but Zanno et al. (2002), who described partial cranial material ascribed to $K$. perfectus, featured the only previous description of such material. Additionally, that specimen (MNA V8415) is from the Blue Mesa Member, which is well below the horizon containing PEFO 35392, and it was assigned solely on the now invalid character of a lacrimal contacting the orbit (Zanno et al., 2002). Cranial material of small metoposaurids is not uncommon in Norian-age sediments, but it is often highly fragmentary and lacking in any diagnostic characters that allow for a designation at the genus level.

The occurrence of a juvenile $K$. perfectus in younger sediments than previously documented for the taxon is important for improving our understanding of the Adamanian-Revueltian faunal turnover, thought to correlate with a climatic shift to an increasingly arid regime with more pronounced seasonality (Dubiel et al., 1991; Parker and Martz, 2011; Nordt et al., 2015). Material of $K$. perfectus is common in Adamanian strata (Blue Mesa Member, lower Sonsela Member) of the park and rare in Revueltian strata (upper Sonsela Member, Petrified Forest Member), while material of A. gregorii demonstrates the inverse distribution pattern (Hunt and Lucas, 1993), which is thought to reflect a climate-associated transition from large metoposaurids to small ones (Parker and Martz, 2011; Atchley et al., 2013). Past workers have cited several features of A. gregorii, including its co-occurrence with a predominantly terrestrial assemblage, poorly developed lateral line system, elongate intercentra, and pelvic structure, as evidence of adaptations for a more terrestrial lifestyle that would have allowed for this transition (Hunt, 1993). However, it should be noted that elongate intercentra, the most commonly recovered material of the taxon, are also found in the much larger Dutuitosaurus ouazzoui (Dutuit, 1976), which is considered fully aquatic (Steyer et al., 2004). Additionally, the presence of a poorly developed lateral line should not be considered equivalent to the absence of a lateral line, as would be expected of truly terrestrial forms. Finally, A. gregorii shares far more features with other metoposaurids in contrast to more definitively terrestrial stereospondyls from the Upper Triassic, such as Rileymillerus Bolt and Chatterjee, 2000, which, in addition to being found with predominantly terrestrial fauna, as with A. gregorii, entirely lacks a distinct lateral line system. We consider it plausible that both the morphological differences and the hypothesized ecological transition could also be explained by life stage niche partitioning. This possibility was previously suggested based on strong negative allometry of Koskinonodon limb bones (Rinehart et al., 2008) and is attractive for several reasons.

Firstly, changes in habitat occupation and skeletal morphology that are associated with the life cycle are common among both extant and extinct amphibians (Wilbur, 1980; Schoch, 2014). Given the pronounced seasonality that characterized the equatorial regions of the Upper Triassic, it would not be unexpected for aquatic taxa, particularly desiccationprone amphibians, to acquire adaptations that would allow them to tolerate more arid conditions during the dry season (Dubiel et al., 1991; Martz and Parker, 2010; Atchley et al., 2013; Nordt et al., 2015). For example, workers have postulated that $M$. diagnosticus, which features more robust forelimbs and musculature relative to Dutuitosaurus ouazzoui (two taxa with well-described articulated skeletons), may have been adapted for burrowing into lake sediments during the dry season (Konietzko-Meier and Sander, 2013). Although any transition from a semi-aquatic to an aquatic lifestyle was not likely as dramatic as the full metamorphosis of extant amphibians, changes to the vertebral column and girdles to accommodate different modes of locomotion and to the otic region to account for different auditory reception are not unreasonable to infer.

Secondly, occupation of different environments would increase the potential for taphonomic bias in addition to that associated with hydrodynamic sorting, which would explain the stark difference in relative abundances between the two taxa (e.g., Loughney et al., 2011). Such a bias is clear in the Blue Mesa Member (middle Norian) at the PEFO based on the 
paucity of juvenile individuals of $K$. perfectus in contrast to the very common adults (Parker and Martz, 2011). Material of A. gregorii is almost exclusively found in blue paleosol horizons at the PEFO, which also preserve the majority of rare taxa in the park, often in a greater degree of articulation than in non-blue paleosol horizons (Loughney et al., 2011). These horizons have been interpreted as abandoned ponds and channels that were fundamentally different in both habitat and depositional settings than the dominant floodplain environments of the Chinle Formation; accordingly, ecological association with different depositional settings between life stages could have produced a taphonomic bias in metoposaurid taxa within the PEFO (Loughney et al., 2011). Such a bias would explain why the assemblages containing A. gregorii are predominantly terrestrial in nature, and could explain both why large metoposaurid specimens are rare in the latest Norian and why this specimen preserves a rare occurrence of associated cranial and postcranial material in contrast to the vast majority of other North American metoposaurid specimens (Hunt, 1993; Heckert and Lucas, 2002; Parker and Martz, 2011). Finally, a semi-aquatic life stage offers one possible explanation for the wide dispersal of large, fully aquatic metoposaurids, which, in addition to the southwest region of North America, are also known from Pennsylvania, Nova Scotia, Europe, Morocco, and India (Hunt, 1993; Long and Murry, 1995). The documented co-occurrence with terrestrial fauna and modestly elongate intercentra in a juvenile $K$. perfectus lend support to the hypothesis of niche partitioning and a semi-aquatic-to-aquatic transition from juvenile to adult life stages.

\section{Conclusions}

The ontogeny of North American metoposaurids is poorly known, largely because of the disarticulated nature of specimens and a lack of identifying cranial features that could differentiate immature specimens of $K$. perfectus from mature specimens of A. gregorii. PEFO 35392, which represents a rare occurrence of associated cranial and postcranial material, contributes additional insight into potential ontogenetically variable features and challenges some of the existing characters used for species discrimination in Metoposauridae. Based on both the external morphology of the skull and the histological analysis of the associated intercentra, otic notches of a more intermediate depth and intercentra of an intermediate degree of elongation may be juvenile features of $K$. perfectus. Accordingly, this specimen highlights the need for more conservative classification of metoposaurid material from western North America, rather than identification based solely on overall size of elements. Given the scarcity of juvenile specimens of $K$. perfectus and the poor understanding of ontogeny of the North American taxa, making a distinction between juvenile individuals of $K$. perfectus and adult specimens of $A$. gregorii is impossible without clear identifying features, which are predominantly cranial features. Additionally, although small size, as well as the lack of otic notches and tabular horns, is the most common feature used to identify A. gregorii, caution should be exercised in assigning specimens with clearly weathered posterior margins because this may remove the tabular horns and make the otic notches appear shallower. Given the current scarcity of well-preserved skulls of A. gregorii, many of the diagnostic characters require further specimens to verify their utility in species discrimination.

Given the invalidity of the lacrimal position as a character for species discrimination, existing classifications of small metoposaurids should be rigorously reassessed (Sulej, 2007; Brusatte et al., 2015). It is important that specimens not be assigned to A. gregorii simply because they lack this single, currently invalid, diagnostic character of $K$. perfectus, the only other metoposaurid known from middle to late Norian sediments of western North America. For example, the specimen (UCMP 175145) ascribed to A. gregorii by Zanno et al. (2002) was classified based on a lacrimal excluded from the orbit and its overall diminutive size; the former is no longer considered valid and the latter has never been a formal character (Sulej, 2002; Brusatte et al., 2015). Specimens must possess diagnostic features of A. gregorii in order to be assigned to the taxon because of the potential morphological overlap with juveniles of another taxon; otherwise, they should be referred only to the most inclusive taxon the characters allow, in this case simply Metoposauridae (Nesbitt and Stocker, 2008). At the same time, caution should also be exercised in utilizing the existing cranial characters, considering that nearly all of the diagnostic cranial features of A. gregorii are based on the holotype skull, with additional specimens needed to corroborate their utility (Hunt, 1993; Spielmann and Lucas, 2012). Additionally, until a better understanding of ontogenetic variation can be achieved in North American metoposaurids, the use of size to identify specimens should be discouraged. Finally, the documentation of a juvenile $K$. perfectus in an assemblage of predominantly terrestrial vertebrates, and that includes intercentra that are of intermediate proportions to those of $A$. gregorii and $K$. perfectus, raises questions regarding the validity of the $A$. gregorii as a species. Because the ontogeny of North American metoposaurids is not well known, features identified by Hunt (1993) in support of Apachesaurus as an adult, rather than a juvenile of a known taxon, require additional study for better evaluation, especially since some assertions were made on the basis of nonmetoposaurid temnospondyls or on a low sample size. Given that ontogenetic changes in limb bone morphology associated with niche partitioning are already documented in $K$. perfectus (e.g., Olsen, 1951), variation in other features may also be associated with occupation of different environments, such as the intercentra or the depth of the otic notches. The hypothesis of life-stage niche partitioning requires further exploration, but offers solutions to several unresolved questions, such as the markedly different relative abundances of the two taxa and the paucity of juvenile specimens of $K$. perfectus. Therefore, these variable features should not be considered for species discrimination unless such variation can be clearly identified as interspecific rather than ontogenetic.

\section{Acknowledgments}

Thanks to M. Smith (PEFO) for granting access to collections for the duration of a National Park Service (NPS) summer internship awarded to BMG, to C. Lash (PEFO) for assistance with molding and casting of the intercentra, and to $\mathrm{B}$. Traver (PEFO) for granting permission for the destructive histological 
analysis of intercentra. Thanks to the Petrified Forest Museum Association (PFMA) for providing funding for the NPS internship. Thanks to Y. Haridy (University of Toronto) for assistance with thin-section preparation. Thanks to T. Sulej and an anonymous reviewer and to the editor, H.-D. Sues for constructive comments that improved the manuscript. This is Petrified Forest National Park Paleontological Contribution No. 47. Any opinions, findings, or conclusions of this study represent the views of the authors and not those of the U.S. Federal Government.

\section{References}

Ash, S., 1992, The Black Forest Bed, a distinctive unit in the Upper Triassic Chinle Formation, northeastern Arizona: Journal of the Arizona-Nevada Academy of Science, v. 24-25, p. 59-73.

Atchley, S.C., Nordt, L.C., Dworkin, S.I., Ramezani, J., Parker, W.G., Ash, S.R., and Bowring, S.A., 2013, A linkage among Pangean tectonism, cyclic alluviation, climate change, and biologic turnover in the Late Triassic: the record from the Chinle Formation, southwestern United States: Journal of Sedimentary Research, v. 83, p. 1147-1161.

Bell, C.J., Gauthier, J.A., and Bever, G.S., 2010, Covert biases, circularity, and apomorphies: a critical look at the North American Quaternary herpetofauna stability hypothesis: Quaternary International, v. 217, p. 30-36.

Billingsley, G.H., 1985, General stratigraphy of the Petrified Forest National Park, Arizona: Museum of Northern Arizona Bulletin, v. 54, p. 3-8.

Bolt, J.R., and Chatterjee, S., 2000, A new temnospondyl amphibian from the Late Triassic of Texas: Journal of Paleontology, v. 74, p. 670-683.

Branson, E.B., and Mehl, M.G., 1929, Triassic amphibians from the Rocky Mountain region: University of Missouri Studies, v. 4, p. 155-239.

Brusatte, S.L., Butler, R.J., Mateus, O., and Steyer, J.S., 2015, A new species of Metoposaurus from the Late Triassic of Portugal and comments on the systematics and biogeography of metoposaurid temnospondyls: Journal of Vertebrate Paleontology, v. 35, p. e912988.

Case, E.C., 1922, New reptiles and stegocephalians from Upper Triassic of western Texas: Carnegie Institution of Washington Publications, v. 321, p. $1-84$.

Case, E.C., 1931, Description of a new species of Buettneria, with a discussion of the brain case: Contributions from the Museum of Paleontology, University of Michigan, v. 3, p. 187-206.

Case, E.C., 1932, A collection of stegocephalians from Scurry County, Texas: Contributions from the Museum of Paleontology, University of Michigan, v. 4 , p. $1-56$

Chowdhury, T.R., 1965, A new metoposauroid amphibian from the Upper Triassic Maleri Formation of Central India: Philosophical Transactions of the Royal Society London B, v. 250, p. 1-52.

Colbert, E.H., and Imbrie, J., 1956, Triassic metoposaurid amphibians: Bulletin of the American Museum of Natural History, v. 110, p. 403-452.

Cope, E.D., 1875, The geology of New Mexico: Proceedings of the Academy of Natural Sciences of Philadelphia, v. 27, p. 263-267.

Danto, M., Witzmann, F., and Fröbisch, N.B., 2016, Vertebral development in Paleozoic and Mesozoic tetrapods revealed by paleohistological data: PloS One, v. 11 , p. e0152586.

Dubiel, R.F., Parrish, J.T., Parrish, J.M., and Good, S.C., 1991, The Pangean megamonsoon-evidence from the Upper Triassic Chinle Formation, Colorado Plateau: Palaios, v. 6, p. 347-370.

Dutuit, J.M., 1976, Introduction à l'étude paléontologique du Trias continental marocain. Description des premiers stegocephales recueillis dans le couloir d'Argana (Atlas occidental): Memoires du Museum National d'Histoire Naturelle, Paris, Series C, v. 36, p. 1-253.

Gee, B.M., Parker, W.G., and Marsh, A.D., 2017, Microanatomy and paleohistology of the intercentra of North American metoposaurids from the Upper Triassic of Petrified Forest National Park (Arizona, USA) with implications for the taxonomy and ontogeny of the group: PeerJ 5: e3183 DOI $10.7717 /$ peerj.3183.

Heckert, A.B., and Lucas, S.G., 2002, Revised Upper Triassic stratigraphy of the Petrified Forest National Park, Arizona, U.S.A.: New Mexico Museum of Natural History and Science Bulletin, v. 21, p. 1-36.

Hunt, A.P., 1989, A new ornithischian dinosaur from the Bull Canyon Formation (Upper Triassc) of east-central New Mexico, in Lucas, S.G., and Hunt A.P., eds., Dawn of the Age of Dinosaurs in the American Southwest: Albuquerque, New Mexico Museum of Natural History, p. 355-358.

Hunt, A.P., 1993, Revision of the Metoposauridae (Amphibia: Temnospondyli) and description of a new genus from western North America: Museum of Northern Arizona Bulletin, v. 59, p. 67-97.
Hunt, A.P., and Lucas, S.G., 1993, Taxonomy and stratigraphic distribution of Late Triassic metoposaurid amphibians from Petrified Forest National Park, Arizona: Journal of the Arizona-Nevada Academy of Science, v. 27, p. 89-96.

Irmis, R.B., 2007, Axial skeleton ontogeny in the Parasuchia (Archosauria: Pseudosuchia) and its implications for ontogenetic determination in archosaurs: Journal of Vertebrate Paleontology, v. 27, p. 350-361.

Konietzko-Meier, D., and Sander, P.M., 2013, Long bone histology of Metoposaurus diagnosticus (Temnospondyli) from the Late Triassic of Krasiejów (Poland) and its paleobiological implications: Journal of Vertebrate Paleontology, v. 33, p. 1003-1018.

Konietzko-Meier, D., Bodzioch, A., and Sander, P.M., 2013 (for 2012), Histological characteristics of the vertebral intercentra of Metoposaurus diagnosticus (Temnospondyli) from the Upper Triassic of Krasiejów (Upper Silesia, Poland): Earth and Environmental Science Transactions of the Royal Society of Edinburgh, v. 103, p. 237-250.

Long, R.A., and Murry, P.A., 1995, Late Triassic (Carnian and Norian) tetrapods from the southwestern United States: Bulletin of the New Mexico Museum of Natural History and Science, v. 4, p. 1-254.

Loughney, K.M., Fastovsky, D.E., and Parker, W.G., 2011, Vertebrate preservation in blue paleosols from the Petrified Forest National Park, Arizona, with implications for vertebrate biostratigraphy in the Chinle Formation: Palaios, v. 26, p. 700-719.

Lucas, S.G., Spielmann, J.A., and Hunt, A.P., 2007, Biochronological significance of Late Triassic tetrapods from Krasiejow, Poland: New Mexico Museum of Natural History and Science, v. 41, p. 48-58.

Lydekker, R., 1890, Catalogue of the Fossil Reptilia and Amphibia in the British Museum of Natural History: Part IV: London, British Museum of Natural History, $295 \mathrm{p}$.

Martz, J.W., and Parker, W.G., 2010, Revised lithostratigraphy of the Sonsela Member (Chinle Formation, Upper Triassic) in the southern part of Petrified Forest National Park, Arizona: PLoS One, v. 5, p. e9329.

Meyer, E., 1842, Labyrinthodonten-Genera: Neues Jahrbuch für Mineralogie, Geographie, Geologie, Palaeontologie, v. 842, p. 301-304.

Mueller, B.D., 2007, Koskinonodon Branson and Mehl, 1929, a replacement name for the preoccupied temnospondyl Buettneria Case, 1922: Journal of Vertebrate Paleontology, v. 27, p. 225.

National Park Service, 2007, National Park Service Museum Handbook: Part III Washington D.C., 554 p. https://www.nps.gov/museum/publications/ MHIII/MHIII.pdf

Nesbitt, S.J., and Stocker, M.R., 2008, The vertebrate assemblage of the Late Triassic Canjilon Quarry (northern New Mexico, U.S.A.), and the importance of apomorphy-based assemblage comparisons: Journal of Vertebrate Paleontology, v. 28, p. 1063-1072.

Nordt, L., Atchley, S., and Dworkin, S., 2015, Collapse of the Late Triassic megamonsoon in western equatorial Pangea, present-day American Southwest: Geological Society of America Bulletin, v. 127, p. 1798-1815.

Olsen, F.R., 1951, Size relations in the limb bones of Buettneria perfecta: Journal of Paleontology, v. 25, p. 520-524.

Parker, W.G., and Barton, B.J., 2008, New information on the Upper Triassic archosauriform Vancleavea campi based on new material from the Chinle Formation of Arizona: Palaeontologia Electronica, v. 11, 14A: 20 p. http:// palaeo-electronica.org/2008_3/158/index.html

Parker, W.G., and Irmis, R.B., 2005, Advances in Late Triassic vertebrate paleontology based on new material from Petrified Forest National Park, Arizona: New Mexico Museum of Natural History and Science Bulletin, v. 29 , p. $45-58$

Parker, W.G., and Martz, J.W., 2011, The Late Triassic (Norian) Adamanian-Revueltian tetrapod faunal transition in the Chinle Formation of Petrified Forest National Park, Arizona: Earth and Environmental Science Transactions of the Royal Society of Edinburgh, v. 101, p. $231-260$.

Ramezani, J., Hoke, G.D., Fastovsky, D.E., Bowring, S.A., Therrien, F., Dworkin, S.I., Atchley, S.C., and Nordt, L.C., 2011, High-precision U-Pb zircon geochronology of the Late Triassic Chinle Formation, Petrified Forest National Park (Arizona, USA): temporal constraints on the early evolution of dinosaurs: Geological Society of America Bulletin, v. 123, p. 2142-2159.

Rinehart, L.F., Lucas, S.G., Heckert, A.B., and Hunt, A.P., 2008, Preliminary analysis of growth and age structure of Buettneria (Amphibia: Metoposauridae) assemblages from the Upper Triassic of West Texas and New Mexico: New Mexico Geology, v. 30, p. 56.

Schoch, R.R., 2009, Life-cycle evolution as response to diverse lake habitats in Paleozoic amphibians: Evolution, v. 63, p. 2738-2749.

Schoch, R.R., 2013, The evolution of major temnospondyl clades: an inclusive phylogenetic analysis: Journal of Systematic Palaeontology, v. 11, p. 673-705.

Schoch, R.R., 2014, Life cycles, plasticity and palaeoecology in temnospondyl amphibians: Palaeontology, v. 57, p. 517-529. 
Spielmann, J.A., and Lucas, S.G., 2012, Tetrapod fauna of the Upper Triassic Redonda Formation east-central New Mexico: the characteristic assemblage of the Apachean land-vertebrate faunachron: Bulletin of the New Mexico Museum of Natural History and Science, v. 55, p. 1-119.

Steyer, J.S., Laurin, M., Castanet, J., and De Ricqlès, A., 2004, First histological and skeletochronological data on temnospondyl growth: palaeoecological and palaeoclimatological implications: Palaeogeography, Palaeoclimatology, Palaeoecology, v. 206, p. 193-201.

Sulej, T., 2002, Species discrimination of the Late Triassic temnospondyl amphibian Metoposaurus diagnosticus: Acta Palaeontologica Polonica, v. 47, p. $535-546$

Sulej, T., 2007, Osteology, variability, and evolution of Metoposaurus, a temnospondyl from the Late Triassic of Poland: Palaeontologia Polonica, v. 64, p. 29-139.

Watson, D.M.S., 1919, The structure, evolution, and origin of the Amphibia. The orders Rhachitomi and Stereospondyli: Philosophical Transactions of the Royal Society of London, Series B, v. 209, p. 1-73.

Wilbur, H.M., 1980, Complex life cycles: Annual Review of Ecology and Systematics, v. 11, p. 67-93.

Witzmann, F., 2013, Phylogenetic patterns of character evolution in the hyobranchial apparatus of early tetrapods: Earth and Environmental Science Transactions of the Royal Society of Edinburgh, v. 104, p. 145-167.
Witzmann, F., Scholz, H., Mueller, J., and Kardjilov, N., 2010, Sculpture and vascularization of dermal bones, and the implications for the physiology of basal tetrapods: Zoological Journal of the Linnean Society, v. 160, p. 302-340.

Woody, D.T., 2006, Revised stratigraphy of the lower Chinle Formation (Upper Triassic) of Petrified Forest National Park, Arizona: Museum of Northern Arizona Bulletin, v. 62, p. 17-45.

Yates, A.M., and Warren, A.A., 2000, The phylogeny of the 'higher' temnospondyls (Vertebrata: Choanata) and its implications for the monophyly and origins of the Stereospondyli: Zoological Journal of the Linnean Society, v. 128 , p. $77-121$.

Zanno, L.E., Heckert, A.B., Lucas, S.G., and Krzyzanowski, S.E., 2002, Diminutive metoposaurid skulls from the Upper Triassic Blue Hills (Adamanian: Latest Carnian) of Arizona: ontogenetic and phylogenetic implications: Journal of Vertebrate Paleontology, v. 22, p. 121-125.

Zittel, K.A., 1888, Handbuch der Paläeontologie. Abteilung 1. Paläozoologie Band III. Vertebrata (Pisces, Amphibia, Reptilia, Aves): Munich, Oldenbourg, $900 \mathrm{p}$.

Accepted 13 March 2017 